\title{
Bunt kobiet w polskiej muzyce tradycyjnej i folkowej
}

\section{Women's rebellion in traditional and contemporary Polish folk music}

\begin{abstract}
DOI: 10.12775 LL.1.2021.004 | CC BY-ND 3.0 PL
ABSTRACT: My assumption is that music can embody political views, organise the human understanding of society and the world, as well as become a political expression, that it has the power to create as well as change social orders. Music often becomes the political voice of the oppressed, whose voice cannot be heard otherwise. Music can be treated as a weapon, but also as a way of dealing with difficult reality. Moreover, I am deeply convinced that this combination of music and politics is a universal, timeless value. To prove this hypothesis, I analysed selected traditional lyrics taken from the ethnographic collections of Oskar Kolberg and contemporary Polish folk songs. They all share a common theme that I have identified as women's rebellion. My aim is to show that certain feminist ideas connect contemporary actions of Polish women with the experiences of their female ancestors.
\end{abstract}

KEYWORDS: traditional music, contemporary folk music, folklore, anthropology of music, feminism, Oskar Kolberg, music and politics.

Oj, nieszczęśliwa moja podola, co to za niewola!

Cicho babo, czarownico, szczekasz babo, nie wiesz o co.

Ty tam zczarowany, boś co dzień pijany.

Co dzień pijany, w domu nie nocujesz, gospodarstwa nie pilnujesz, rujnujesz, rujnujesz, rujnujesz.

(Kolberg 1963c: 230) 
Muzyka ludowa jest wesoła, służy do zabawy i tańca, pieśni opowiadają o zalotach i potańcówkach - takie potoczne opinie nadal można spotkać. I owszem, muzyka na wsi była dawniej nieodłącznym elementem wesel i potańcówek, służyła wspólnotowemu radowaniu się. Ale... nie tylko. Niektórzy za takie zbanalizowanie wizji muzyki tradycyjnej winili (a może nadal winią) Oskara Kolberga. Zbiorom ojca polskiej etnografii krytycznie przyglądał się przede wszystkim Ludwik Stomma, podliczając, że w swoich opasłych tomach Ludu aż 84\% treści poświęcił on „wesołym zajęciom, związanym przede wszystkim z czasem wolnym”. Same zaś zapisy pieśni i tańców miały zajmować 50\% treści tomu Mazowsze (Stomma 1986: 236). Z pewnością przedstawiciele XIX-wiecznego „ludu” nie spędzali aż połowy swojego życia na tańcach i śpiewach. $Z$ pewnością też romantyczni i pozytywistyczni zbieracze folkloru przyczynili się do wykształcenia pewnego mitu ludowości, który operował zniekształconymi obrazami wiejskiej rzeczywistości (por. Kowalski 2004). Sądzę jednak, że krytykując Kolberga, warto mieć na uwadze kilka spraw. Po pierwsze był on z wykształcenia muzykiem i kompozytorem, a zatem naturalnie te treści najbardziej go interesowały; zresztą dla etnomuzykologów jego zbiory są absolutnie nieocenionym źródłem wiedzy o dawnym wiejskim repertuarze (Grozdew-Kołacińska 2014). Po drugie czas, w którym działał, czyli druga połowa XIX w., nadal zdominowany był przez ludoznawcze zbieractwo, w kontekście którego Kolberg wyrastał na absolutnego innowatora i postępowca, jeśli chodzi o sposób pozyskiwania materiałów, zestawiania ich, a także rozmiary jego pracy (Waszczyńska 2014). Próby oceniania jego pracy z perspektywy osiągnięć współczesnej antropologii wydają się nietrafione. Po trzecie zaś, i o tym chyba mówi i pisze się najrzadziej, z analizy zapisów pieśni i tańców niekoniecznie wyłania się obraz wsi kolorowej, wesołej i roztańczonej. Wiele w nich bowiem smutku, rozpaczy, wymarzonych wizji rzeczywistości, wyobrażeń świata na opak, treści historycznych a także politycznych.

Zarówno badacze, jak i wykonawcy tradycyjnej muzyki wiejskiej doskonale wiedzą, że poza utworami atrakcyjnymi dla szerokiej publiczności, najczęściej prezentowanymi przez różne zespoły pieśni i tańca, w materiałach ludoznawców i etnomuzykologów znajduje się wiele pieśni pogrzebowych, przeznaczonych na czas żałoby, ballad opowiadających dramatyczne historie żołnierskie a nawet kryminalne, a także pieśni, które po prostu opisywały trudne codzienne życie chłopów pańszczyźnianych. Bardzo interesujące wydaje mi się to, że z tych niewesołych treści dawnego folkloru często korzystają dziś artyści folkowi, którzy inspirując się dawną tradycją wiejską, na jej podstawie tworzą całkiem nowe muzyczne konstelacje.

Tekst pieśni, którą umieściłam na początku niniejszego artykułu, pochodzący ze zbiorów Kolberga (1963c), to lament mężatki ubolewającej nad swoim losem. Kobieta nazywa go niedolą i niewolą jednocześnie. Skarży się na niedobrego męża alkoholika, który roztrwania cały gospodarski dobytek. Słowa tej pieśni wyraźnie pokazują zarazem, jakie było miejsce kobiety w hierarchii domowej. Jej lamenty na nic się nie zdadzą - marudząca żona to czarownica, a jej narzekania potraktowane zostaną co najwyżej tak, jak szczekanie psa. Niech siedzi cicho. Analizując krytycznie teksty pieśni zanotowane przez Oskara Kolberga, doszłam do wniosku, że są one wstrząsającym zapisem dramatycznego losu kobiet wiejskich z XIX w. Sądzę też, że być może właśnie śpiewanie było jedną z niewielu możliwych form artykułowania nie tylko bólu, ale także sprzeciwu i buntu wobec rzeczywistości. 
Wychodząc z powyższego założenia, postaram się w niniejszym tekście ukazać treści feministyczne obecne w polskiej muzyce tradycyjnej a następnie zanalizować sposoby wykorzystywania tego tradycyjnego idiomu buntowniczego przez współczesne artystki sceny folkowej. Wybrane przeze mnie pieśni ze zbiorów Oskara Kolberga oraz utwory współczesne stanowią jedynie pewne przykłady ilustrujące procesy i działania kulturowe o znacznie szerszym zakresie. Tego typu spisanych świadectw kobiecej niedoli w materiałach etnograficznych i twórczości dzisiejszych artystek jest bowiem znaczenie więcej.

\section{Muzyka, polityka i kobiety}

Zanim przystąpię do analizowania konkretnych materiałów etnograficznych i muzycznych, pragnę poczynić kilka teoretycznych uwag. Po pierwsze nie będę się tu odnosić do spraw genderowego umiejscowienia kobiet w przestrzeni muzycznej. Wiele już na ten temat napisano, powstały prace tłumaczące niewielką liczbę wiejskich muzykantek, a także płciowe uwarunkowania marginalizacji kobiet grających (Kizińska 2012; Koskoff 2014; Małanicz-Przybylska 2014; Nowak 2016). To ważne tematy dla folklorystyki feministycznej, jednak w tym przypadku interesować mnie będą raczej sposoby podejmowania działań o charakterze politycznym (a szczególnie feministycznym¹) poprzez muzykę. Sądzę, że związki muzyki z polityką nie są tak oczywiste, jak czasami chce się o nich myśleć. Naturalnie muzyka może intensyfikować społeczne emocje (Gwizdalanka 1999), może wywierać nacisk na władze wyrażony w protest songach, może także wspierać konkretne polityki i wizje świata (Street 2012) - wtedy mówimy o muzyce stricte politycznej. Jednak ja chcę rozumieć sferę przenikania się muzyki i polityki szerzej. Bliskie jest mi podejście Johna Streeta, który pisał, że muzyka i polityka nie powinny być postrzegane jako oddzielne przestrzenie, które stykają się tylko okazjonalnie. Należy je raczej rozumieć jako wzajemne przedłużenia. Muzyka ucieleśnia bowiem polityczne wartości i ekspresje, organizuje i porządkuje nasze rozumienie społeczeństwa jako struktury politycznej z jej konkretnymi działaniami. Muzyka nie jest więc, jak ujął to Street (2012: 1), nosicielką politycznych treści, ona sama staje się polityczną ekspresją. W podobny sposób o muzyce jako sposobie działania pisała Tia deNora (200o). Badaczka uważa muzykę za potężne medium społeczne służące zarówno do konstruowania jednostkowych i zbiorowych tożsamości, jak też do kreowania i zmieniania porządków społecznych. Muzyka jest formą praktyki, ale bywa też źródłem zasobów i środków niezbędnych do kształtowania rzeczywistości, a więc może dostarczać podstaw do podjęcia konkretnego działania. Mówiąc prościej, deNora uważa, że muzyka służy ludziom do myślenia, wyobrażania, motywowania czy też organizowania działania (2020: 17). Takie podejście skłania - jak pisała Maureen Mahon (2014: 329) - do „badania sposobów, w jakie ludzie komunikują, reprodukują, a czasami zmieniają relacje władzy poprzez swoje zaangażowanie w przestrzenie kultury ekspresyjnej”. Antropolożka ta, prowadząca badania wśród afroamerykańskich artystek rockowych, uważa ponadto, że właśnie poprzez artystyczną ekspresję ludzie mogą reagować na politykę, ale też radzić sobie z opresją władzy oraz z prawdziwymi problemami codzienności (Mahon 2014: 327).

1 Ponieważ w pracy będę przywoływać przykłady pochodzące z różnych czasów i kontekstów kulturowych, słowo „feminizm” chcę tu traktować możliwie szeroko, jako wszelkie działania, ruchy, a nawet gesty mające na celu poprawę złej sytuacji kobiet lub nawet tylko jej wskazanie i nazwanie. 
Przypuszczam, że tak pojęte polityczne znaczenie ekspresji muzycznych można odnaleźć w tekstach dawnych pieśni wiejskich śpiewanych przez kobiety. Jest to oczywiście jedynie hipoteza. Nie mam już natomiast wątpliwości, że wykorzystując ten dawny materiał jako inspirację do działan artystycznych, współczesne muzyczki i wokalistki świadomie angażują się w politykę, czując swoją sprawczość. Nie tylko chcą opowiadać o złym losie kobiet, ale też pragną go zmieniać.

\section{Treści buntownicze i feministyczne w tradycyjnych pieśniach wiejskich}

W polskim dyskursie akademickim i publicznym pojawia się ostatnio coraz więcej publikacji, które rzucają całkiem nowe światło na kwestie pańszczyzny, systemu feudalnego i przede wszystkim życia chłopów w dawnej Polsce. Warto wymienić tu choćby Ludowa historię Polski Adama Leszczyńskiego (2020) poświęconą kwestiom relacji władzy, dziejom wyzysku i chłopskiego oporu oraz Chamstwo, najnowszą książkę Kacpra Pobłockiego (2021). Kwestiom chłopskich buntów i sposobom stawiania oporu panom a nawet całemu systemowi przyjrzał się również Michał Rauszer w swojej pracy Bękarty pańszczyzny. Książka ta - zadeklarował autor we wstępie - „ma pokazać, w jaki sposób nasi przodkowie wyrażali niezgodę na system, który w ich przekonaniu był niesprawiedliwy” (Rauszer 2020: 13). Chłopi bardzo rzadko wzniecali jawne bunty (one najczęściej kończyły się dramatycznie; Rauszer określił je nawet mianem „aktów samobójczych”), jednak wypracowali inne taktyki, sposoby działania lub zaniechania działań, które można postrzegać jako akty dywersyjne, ale także jako próbę radzenia sobie w trudnej rzeczywistości. $\mathrm{Z}$ punktu widzenia niniejszych rozważań najistotniejsze wydaje mi się stwierdzenie Rauszera, że jedną z form chłopskiego oporu stawała się ich twórcza ekspresja, której wyraz dawali między innymi w muzyce, w pieśniach. Folklor okazywał się bezpieczną formą przekazu pewnych buntowniczych treści. Jego anonimowość gwarantowała bezpieczeństwo. „Do panów docierały pieśni, których słowa były skierowane przeciwko nim, ale $\mathrm{z}$ uwagi na to, że pieśni te nie miały autora, nie można go było ukarać” (Rauszer 2020: 72). Zamknięty w pieśniach głos „ludu” stał się dla Rauszera jednym ze źródeł użytych do rekonstrukcji chłopskiego światopoglądu oraz obrazu stosunku chłopów do panów i pańszczyzny. Słowa pieśni przywoływanych przez autora stają się świadectwem złej pańsko-chłopskiej relacji:

Oj wygrał, nasz pan wygrał, wszystkich chłopów ze wsi wygnał.

I stodoły powywracał i służącym nie wypłacał.

Oj dobrześ parchu zrobiuł, będziesz sam na siebie robiuł.

(Kolberg 1963: 209; za Rauszer 2020: 89)

Postaram się podążyć tą samą drogą, to znaczy na podstawie wybranych pieśni wiejskich zrekonstruować feministyczny obraz świata moich przodkiń, a przede wszystkim zastanowić się, przeciwko czemu się one buntowały, jakie treści swojego życia wskazywały jako najtrudniejsze, najbardziej dramatyczne, poniżające, przynoszące cierpienie.

Powróćmy na chwilę myślami do pieśni przytoczonej przeze mnie jako motto niniejszego artykułu. Poruszony w niej wątek pijących mężczyzn pojawia się też w wielu innych pieśniach, co moim zdaniem świadczy o skali tego problemu: 
Nie chce cie, dziewcyno, bo brudne nogi mas.

I ja ciebie nie chce, bo gorzałke pijas.

Pójde ja do rzeki umyje se nogi,

a ty pijes, w karty grywas i bedzies ubogi.

Nie uwazaj na to, gdy zbiere me smaty,

przedam je Zydowi i bede bogaty.

Oj, nie chcę cie, chłopce, oj, nie chcę cie wcale, przepiłbyśs swe smaty i moje korale.

(Kolberg 1963d: 182)

Konsekwencją pijaństwa mężczyzn najczęściej okazywała się bieda. Oczywiście niedostatki różnego rodzaju stawały się udziałem większości chłopów pańszczyźnianych, ale właśnie dlatego trwonienie pieniędzy na alkohol bywało dramatyczne w skutkach ${ }^{2}$. Powyższa piosenka niby ma żartobliwy charakter. Kiedy jednak przyjrzymy się uważniej jej słowom, okaże się, że wyrażają one ogromne obawy dotyczące przyszłego życia. Obawy te zaś niewątpliwie wynikały z doświadczenia tych kobiet, które musiały żyć z mężami pijakami. Pijaństwo generowało bowiem nie tylko biedę, ale także przemoc domową:

Ny kto ne wynien, sama ja, żem polubyła hultaja.

A mój hultaj w korczmi pije, pryjde do dom, mene byje.

(Kolberg 1968: 382)

Przed tą męską agresją i fizyczną przemocą trudno było uciec. W wielu piosenkach pojawiają się podobne frazy opowiadające o próbach wzywania pomocy:

Już, już, już, już, mąż mnie bije, któż mnie tera pożałuje?

Moja matko, przyjedź do mnie, moja matko, pożałuj mnie!

(Kolberg 1963c: 80)

Najczęściej jednak ani matka, ani ojciec, ani bracia nie byli w stanie niczemu zaradzić. Żona nie należała już do nich, była „własnością” męża oraz jego rodziny (por. Stomma 1986; Mędrzecki 1995). Szczególnie niekorzystna była domowa sytuacja młodych mężatek. Wchodząc dopiero do nowej rodziny, były w niej obce, dlatego w przypadku jakichkolwiek konfliktów pozostali członkowie brali stronę męża, nie kobiety. W pieśniach poruszających te problemy najwięcej skarg i lamentów dotyczy teściowych, złych matek:

Niescęśliwy ten jest, kto na matkę posed, bo mężowska matka jak kolący oset.

A kolącym ostem można płoty grodzić, męzowskij macierzy, nigdy nie dogodzić.

(Kolberg 1964: 314)

2 Na marginesie warto przypomnieć, że Józef Burszta postrzegał rozpijanie chłopów przez szlachtę jako jeden z ważnych elementów gospodarki pańszczyźnianej (Burszta 1950). 
Sądzę, że w ogólnej perspektywie sytuację młodych kobiet na dawnej wsi można postrzegać jako opresyjną. Z jednej strony ich społeczną powinnością było wyjście za mąż i urodzenie dzieci - do tego były od dziecka socjalizowane. $Z$ drugiej jednak strony konieczność poślubienia wskazanego przez rodzinę mężczyzny mogła budzić wewnętrzny sprzeciw. W wielu przypadkach małżeństwa zawierano przecież jako wynik transakcji ekonomicznych, a oczekiwania i preferencje dziewczyny nie miały tu żadnego znaczenia, o czym też śpiewano:

Jakze nie mam smutna być, za starego kazą iść.

Oj stary, stary, lepiej mu na mary, a mnie lepiej panną być.

(Kolberg 1962: 144)

Świadectwem obaw, a nawet rozpaczy młodych kobiet, które zmuszone były wziąć ślub wbrew własnej woli, z pewnością mogą być także niektóre z pieśni weselnych śpiewanych dawniej przez drużki:

Wyszła dziewczyna, wyszła jedyna, jak róży kwiat.

A jak wziena płakać, jak wziena wyrzekać, zmienił sie i [jej] świat.

Czego ty płaczesz, czego wyrzekasz, kochanie moje?

Jak nié mam płakać i nié mam wyrzekać, nié będę twoją.

(Kolberg 1963a:177)

Kobiety narażone były także na przemoc seksualną. Nie udało mi się odnaleźć takich pieśni, które z całą pewnością można by uznać za świadectwo gwałtów dokonywanych wewnątrz wiejskiej wspólnoty. Tomasz Wiślicz, historyk chłopskiej seksualności, analizując dokumenty wiejskich sądów, trafił jednak na źródła poświadczające takie zdarzenia:

Katarzyna oskarżyła Dumkę o gwałt, wiedzieć jednak nie można, żeby onę zgwałcił; owszem, gdyż ważyła się sama z nim z karczmy wyniść i do domu przyjść, zezwolenie jej na tenże uczynek bardziej się pokazuje (Wiślicz 2012: 45)

W innym zeznaniu sądowym przytaczanym przez Wiślicza młoda dziewczyna opisywała takie zdarzenie:

Szczepan Łyczko w niedziele po Bożym Narodzeniu idąc z moją matką z karczmy Borsuk zwanej zszedł do moich rodziców chałupy i najadłszy się, jak ja wyszła do stajni bydło napasać, poszedł za mną, namawiał mnie różnemi słowami na uczynek cielesny, a gdym zezwolić nie chciała, obiecał się ze mną żenić, a nie mogąc mnie jeszcze i tym dla siebie nakłonić, jakem mu się wydzierała, przewrócił mnie w stajni, i zatkawszy mi gębę chustką z mojej głowy zdjętą z resztą dołożywszy siły, swoją wolę wypełnił (Wiślicz 2012: 47).

Choć badania Wiślicza dotyczyły dokumentów z czasów przedrozbiorowych, można jednak podejrzewać, że gwałty dokonywane przez chłopów miały miejsce i później. Czemu więc o nich nie śpiewano lub śpiewano niewiele? Być może takie doświad- 
czenia stawały się udziałem niewielu kobiet. Z badań Tomasza Wiślicza (2012) wynika, że życie seksualne młodzieży wiejskiej cechowała dawniej duża swoboda, być może zatem i zdefiniowanie gwałtu nie było sprawą oczywistą. Są to jednak tylko moje przypuszczenia.

Natomiast sprawa wyglądała całkiem inaczej, jeśli chodzi o gwałty dokonywane na chłopkach przez panów. Przed tego rodzaju czynami kobiety właściwie nie miały się jak bronić. Nawet wiejska wspólnota niewiele mogła poradzić. Jeśli przychodził pan i chciał „wziąć” chłopkę, brał. Ten rodzaj gwałtów działał na zasadzie przemocy systemowej, zinstytucjonalizowanej. Opowiadają o tym m.in. słowa ballady zanotowanej przez Oskara Kolberga, w której to pańscy słudzy przychodzą do wsi po wybraną dziewczynę i prowadzą ją do „mości pana”:

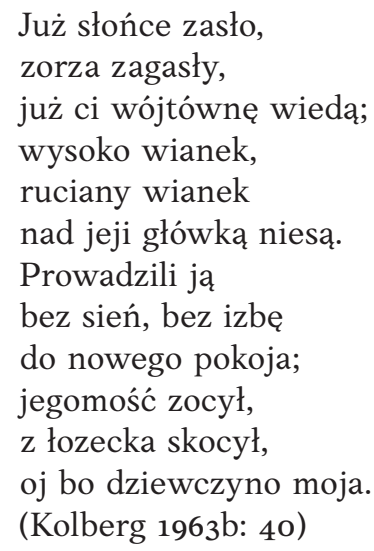

Dziewczyny były w takich sytuacjach pozbawione jakiejkolwiek możliwości sprzeciwu, nie miały też kogo wołać na pomoc ${ }^{3}$. Jednym ze sposobów reagowania na dramaty gwałtów stawały się właśnie pieśni.

O sprawach dotyczących seksualności - zarówno tej pożądanej, jak i przemocowej - często wyrażano się w sposób symboliczny:

Szła Marysia po wodę, miała piękna urodę

i nadszed ją pan, pan, co jej rozbił dzban.

(Kolberg 1968: 338)

Trudno mieć złudzenie, co ów „dzban” oznacza. Znalazłam jednak w zbiorach Kolberga także bardziej jednoznaczne treści:

A chodziła po lesie, da, sukała cielęcia, i wstąpiła do dworu, i nalazła dziecięcia.

3 Michał Rauszer podaje jednak kilka pojedynczych i skrajnych sytuacji, w których chłopi zbiorowo dokonywali zemsty na pańskich gwałcicielach. Na przykład w trakcie rabacji galicyjskiej chłopi zamordowali ekonoma Jana Stradomskiego, który „wielokrotnie dopuszczał się na chłopkach brutalnych gwałtów. Za to w trakcie rabacji odarto go z ubrania, pobito, odcięto mu penisa i wepchnięto do ust, kiedy dogorywał" (Rauszer 2020: 96). 
A bodaj się i było, da, to ciele i wściekło, oj, nizeli mi było, da, do dworu uciekło! A bodaj to i byli, da, wilcy ciele zjedli, oj, niżeli mnie dworscy, da, do stajni zawiedli! (Kolberg 1962: 146)

Owocem zarówno gwałtów jak i przedmałżeńskich stosunków seksualnych bywały dzieci. Niechciane ciąże również stanowiły przedmiot obaw niezamężnych dziewczyn. Jak wynika z badań Tomasza Wiślicza, najlepszym rozwiązaniem takiego kłopotu był ślub ojca dziecka z ciężarną dziewczyną. Badacz stwierdził, że „[w]iejska opinia publiczna preferowała takie rozwiązanie, a wahających się potrafiła zmusić do ślubu“ (Wiślicz 2017: 131). Nie zawsze jednak się to udawało. Jak już wspominałam, wśród młodzieży na wsi panowała dosyć duża swoboda seksualna, a wspólnota wiejska ją tolerowała, czasem nawet aprobowała. Sytuację zmieniała jednak niechciana ciąża, która stawała się jawną oznaką „grzechu”. Jeśli więc chłopak nie chciał ożenić się z dziewczyną, to głównie ona zyskiwała złą reputację. Mamy tu zatem jeszcze jeden dowód dyskryminacji wiejskich kobiet, sprowadzający się do nierównego traktowania żeńskiej i męskiej seksualności. Mężczyźni mieli dużo większe przyzwolenie na łamanie różnych norm.

Z wychowaniem „bękartów” wiązały się kłopoty natury ekonomicznej. Jednak z treści niektórych pieśni można wysnuć wniosek, że mężczyźni uciekający od odpowiedzialności za wychowanie własnych dzieci - nawet tych nieślubnych - podlegali pewnej społecznej ocenie wyrażonej chociażby w taki sposób:

Idzie Kaśka bez wieś drogą,

a Maciuś też fiku-mik, tą kulawą nogą.

Maciuś, stój, Maciuś, stój,

nie omijaj domek mój, nie omijaj domek mój.

Jak się Kaśka pogniewała, oknem dzieci fik mik powyrzucała,

łopatą, łopatą: a za tatą, za tatą, psie bękarty za tatą.

(Kolberg 1963b: 100)

Niekiedy sytuacja panien w niechcianej ciąży była tak dramatyczna, że podejmowały one decyzję o pozbyciu się dziecka. Znane są z dawnych przekazów praktyki „spędzania płodów”. Jeśli jednak okazywały się one nieskuteczne i niechciane dziecko przyszło na świat, czasem kobiety uciekały się do dzieciobójstwa. Bez względu na to, jak powszechnie stosowano tę praktykę (Wiślicz 2014: 141-151), sądzę, że dla kobiety takie zdarzenie lub działanie musiało jawić się jako dramatyczne, bo właśnie pełne grozy są śpiewane historie o dzieciobójstwie. Jedna z nich opowiada o dziewczynie, której ukochany zginął, dlatego też postanawia ona pozbawić życia najpierw swoje dziecko, a później siebie samą:

Skocyła dziewczyna z ganku wysokiego, wyrwała ostry miec z boku Jasiowego.

Wyrwała, wyrwała i przebiła siebie, małe dzieciątecko puściła na wodę: 
Płyńze, dzieciątecko, jak te modre kwiatki, nie znałoś ty ojca, nie znajze ni matki.

(Kolberg 1964a: 292-293)

W znanym eseju Kres kultury chłopskiej Wiesław Myśliwski napisał, że „chłop przez wieki niewolny, w jednym był zawsze wolny - w słowie“. Esej ten kończy się innym, równie ważnym dla mnie stwierdzeniem. Autor napisał, że na styku słowa, pamięci i wyobraźni „kultura chłopska, przechodząc dziś w sfere już tylko tęsknoty i sztuki, przekazuje nam swoje nie stanowe, lecz w najpełniejszym tego słowa znaczeniu człowiecze dziedzictwo“ (Myśliwski 2003: 60). Sądzę, że właśnie do tego człowieczego dziedzictwa odwołują się współczesne artystki folkowe, które czerpią „ludowe” inspiracje do muzycznych i politycznie zaangażowanych działań na rzecz kobiet.

\section{Folkowa rebelia}

Wiejskie pieśni bólu, buntu, niewoli - zarówno te dotyczące niedoli chłopów pańszczyźnianych, jak i niedoli kobiecej - niemal całkiem zniknęły z praktyki muzycznej w XX w. Repertuar wsi ulegał wówczas ogromnej zmianie. Radio oraz docierające na wieś nowe instrumenty zdecydowanie przyczyniały się też do zmiany upodobań estetycznych (Dahlig 1987). Zespoły folklorystyczne i uczestnicy festiwali muzyki tradycyjnej raczej wybierali repertuar pogodniejszy. Taką tendencję dostrzegali również muzycy folkowi, którzy na początku XXI w. jeździli po wsiach w poszukiwaniu inspiracji. Jak stwierdził Maciej Szajkowski, „[m]uzykanci [...] woleli inne, milsze historie, o graniu na weselach, dawnych tańcach i pieśniach, swoich faworytach i konkurentach, folklorze, obyczajach, etc. To przemijające uniwersum ich kultury“ (Dobrowolski, Szajkowski 2011). Ponieważ moda na folk inspirowany polską muzyką tradycyjną w tamtym czasie rosła, owych poszukiwaczy było coraz więcej. Należeli do nich między innymi członkowie Kapeli ze Wsi Warszawa - wiodącej i do dziś jednej z najpopularniejszych polskich grup folkowych - którzy chyba jako pierwsi zaczęli sięgać po wiejski repertuar dotyczący trudnych treści. Już na ich płytach z początku XXI w. - Wiosna ludu (2001) i Wykorzenienie (2004) pojawiły się utwory odnoszące się do pańszczyzny i chłopskiej niedoli. Lider zespołu Maciej Szajkowski postanowił właśnie te pieśni uczynić głównym tematem innego folk-punkowego projektu R.U.T.A. Myślę, że w pewnym sensie to właśnie ten projekt przyczynił się do wprowadzenia tematu niedoli chłopów pańszczyźnianych do debaty publicznej. Sądzę też, że pierwsza płyta zespołu R.U.T.A., czyli Gore - Pieśni buntu i niedoli XVI-XX wieku, była przełomowa nie tylko dla świata muzycznego. Artyści zdawali się głośno krzyczeć, że:

I Rzeczpospolita oprócz swych blasków i potęgi, była wielką wewnętrzną kolonią, obozem pracy przymusowej, w którym niewielka, dziesięcioprocentowa grupa oligarchów, klika, która podzieliła kraj na własne strefy wpływów i żerowała na katorżniczej pracy osiemdziesięciu procent ludności. Niewolnictwo, którego doświadczyły narody obu Ameryk czy Afryki, było udziałem ludu w naszym kraju. Władzę sprawowali nieudacznicy, ignoranci nie mający pojęcia o rządzeniu własnym dworem, a co dopiero państwem. Panowie, mający 
w nosie przestrzeganie jakiegokolwiek prawa, doprowadzili kraj, wielkie europejskie imperium, do upadku gospodarczego i politycznego, a naród na skraj nędzy ekonomicznej i moralnej (Dobrowolski, Szajkowski 2011).

Poza pieśniami, których treści odnosiły się do pańszczyźnianego ucisku, na płycie znalazły się także utwory wskazujące na rolę kościoła i księży w upodlaniu chłopów, np. Ksiyndza z kazalnicy zrucić i Hej, wielebny bracie. Słowa tej ostatniej piosenki zwracają uwage na nadużycia seksualne przedstawicieli duchowieństwa i bezkarność kleru:

Hej, wielebny bracie, jesteś nietykalny, bo w ornacie?

Czy na to masz łeb wygolony, byś uwodził dzieci, córki, żony?

Hej, Diable!

(R.U.T.A. 2011)

Te antyklerykalne treści wzbudziły wiele kontrowersji, a nawet stały się przyczyną odwoływania koncertów (Kowalski 2011). Artyści wyraźnie podkreślali, że chodzi im nie tylko o oddanie sprawiedliwości historycznej, ale że te dawne pieśni chłopskie obnażają ważne ponadczasowe treści. Jak zaznaczył Maciej Szajkowski, „R.U.T.A. jest wskazaniem na praprzyczynę naszych narodowych przywar, frustracji, problemów, obecnej kondycji społecznej. Tą praprzyczyną jest pogarda człowieka wobec człowieka, z której rodzi się wszelkiej maści wyzysk i niesprawiedliwośćc (Dobrowolski, Szajkowski 2011). Na drugiej płycie zespołu, zatytułowanej Na uschod. Wolność albo śmierć, znalazł się też utwór Prawo pierwszej nocy, w którym wykorzystano tradycyjne teksty wiejskie mówiące o gwałtach panów na chłopkach. A więc już tam pojawiły się wątki kobiece. $Z$ tych wszystkich powodów projekt R.U.T.A. należy uznać za zdecydowanie polityczny i społecznie zaangażowany.

Zaryzykuję stwierdzenie, że to właśnie R.U.T.A. zapoczątkował pewien rodzaj artystycznej ekspresji, która łączyła w sobie treści wiejskiej tradycji z potencjałem politycznym. Od tamtej pory podobne wątki zaczęły pojawiać się w twórczości różnych zespołów. Jednak pierwszym w pełni kobieco-feministycznym projektem folkowym okazała się płyta Czarny war zespołu Pochwalone. To ważne, że założyły go dziewczyny, które należały również do R.U.T.Y. Już sam pomysł na stworzenie takiego zespołu był motywowany politycznie, jak bowiem można przeczytać na stronie producenta „[p]łyta Czarny war to odpowiedź na niewystarczającą obecność żeńskich głosów w muzyce zaangażowanej” (Pochwalone b.d.). Zdecydowane zaangażowanie artystki uczyniły swoim mottem i manifestem:

POCHWALONE to projekt kobiecy. Ludowy a współczesny. Dzisiejszy jak sprzed wieków. O tym, co kobiet dotyczy i co je dotyka. Wspólnota doświadczeń, bunt przez pokolenia, moce, niemoce, darcie pierza, kluby i igraszki. Nowe sensy na przecięciach. Baby, feministki, matki i singielki, podlotki i wiedźmy, dzieweczka z laseczka, ochrypła kukułeczka - one z XIX-wiecznej wsi, one z ursynowskiego bloku - razem! Niech będą pochwalone! (Pochwalone b.d.). 
Artystki otwarcie nazwały się formacją feministyczną. Zestawiając słowa pieśni tradycyjnych z tekstami pisanymi współcześnie, chciały przede wszystkim krzykiem opowiadać o wspólnocie doświadczeń kobiet z przeszłości i współczesnych, pokazać, że przemoc, gwałty, oskarżenia, niemoce społeczne - to wszystko było i nadal trwa. Punkowa stylistyka wzmogła buntowniczy charakter przekazu, podobnie jak było to w przypadku R.U.T.Y.

Kolejnym feministycznym projektem korzystającym z muzyki tradycyjnej stały się działania zespołu Same Suki. Już dwuznaczna nazwa nie pozostawia wątpliwości, że to zespół zaangażowany - grające na sukach biłgorajskich artystki kreują się na silne, wyzwolone kobiety ${ }^{4}$, które potrafią walczyć o swoje, choć niektórzy chcieliby określać je wulgarnymi słowami. Na stronie internetowej zespołu można przeczytać:

Punktem wyjścia dla powstania piosenek zespołu są melodie i teksty ludowe - te zasłyszane na podwórku, te nauczone w domu i te znalezione w książkach etnograficznych. Same Suki z poszukiwań w muzyce źródeł tworzą muzykę eklektyczną i zaangażowaną we wszystkie ważne dla zespołu sprawy - ekologię, prawa kobiet, miłość, seks, odnajdywanie siebie i swojego głosu (O Samych Sukach b.d.).

W niektórych utworach artystki wykorzystują fragmenty tradycyjnych pieśni wiejskich (także tych zanotowanych przez Oskara Kolberga), tworząc z nich własne warianty i tekstowe kolaże. Tak na przykład powstał utwór Biczysko, który w sugestywny sposób ukazuje problem przemocy domowej jako struktury długiego trwania:

Bił mnie w komorze, bił mnie na dworze, bił mnie na wiórzysku.

Wycion me w łepek, podarł my czepek, wytrzaskał po pysku.

(Same Suki 2018)

W poezji wiejskiej pojawiały się oczywiście wyobrażenia zemsty. Jednak zazwyczaj należały one do sfery fantazji i konwencji świata na opak. W wykonaniu Samych Suk motywy takie brzmią inaczej, zdają się prawdziwym nawoływaniem do działania, do obrony, do walki:

Wyparz mu oczy, połam mu nogi i go przewleczesz przez cztery progi. Przez cztery progi, przez cztery kije, napatrz się, mężu, jak żona bije! (Same Suki 2018)

Z kolei w utworze Siedem artystki wykorzystały słowa pieśni dziadowskiej rozpoczynającej się od słów „A w niedzielę z porania”. To szczególny przykład pieśni,

4 W 2020 r. do składu dołączył kontrabasista - mężczyzna. Wszystkie opisywane przeze mnie utwory powstały jednak wcześniej. Warto natomiast nadmienić, że w marcu $2021 \mathrm{r}$. Same Suki na swoim fanpage’u na Facebooku opublikowały manifest, w którym zadeklarowały: „Wreszcie wiemy kim jesteśmy. Jesteśmy zespołem, który używa suki jako pretekstu i podtekstu, który z kobiecej formacji folkowej stał się mieszanym składem bez kontekstu płci i zaburzył tym kolejne szufladkowanie w waszych głowach“. 
która przetrwała do naszych czasów w tzw. żywym repertuarze, to znaczy była wykonywana w różnych sytuacjach i okolicznościach, także na przeglądach i festiwalach folklorystycznych. Również liczne zespoły folkowe dokonywały jej opracowań $^{5}$. Bohaterką jest dziewczyna, która za zamordowanie swoich siedmiorga dzieci zostaje porwana przez „szatańca” do piekła. W tekście pojawiają się obrazowe i przerażające opisy tych siedmiu morderstw. Oczywiście można te treści rozumieć jako historię grozy, wiejski horror, jednak dawniej ta pieśń niosła ze sobą również przesłanie dydaktyczno-moralizatorskie. Odwołując się do koncepcji chrześcijańskich, ale zarazem patriarchalnego modelu kultury tradycyjnej, ukazywała kobiete jako wcielenie zła, istotę okrutną i zdolną do najgorszych zbrodni. Same Suki nadały jej jednak zdecydowany wydźwięk feministyczny. W wywiadzie dla „Wysokich Obcasów” opowiadały o tym tak:

Nie chodzi nam ani o piętnowanie kobiet, które zabijają swoje dzieci - bo choć to tekst z XVI wieku, temat jest ciągle aktualny - ani o ich usprawiedliwianie. Chodzi o zwrócenie uwagi na problemy, które je do tego doprowadzają. Zamiatanie pod dywan prowadzi do tego, że wciąż odkrywamy szkielety w beczkach i dziwne zawiniątka zakopane za stodołą (Wiechnik 2014).

A zatem wykorzystując dawną balladę, artystki chciały zwrócić uwage na ponadczasowy problem dramatycznego położenia wielu kobiet i równie dramatycznych prób wyjścia z opresji. Warto też odnotować, że piosenka Siedem została wykorzystana przez działaczy proaborcyjnych. Według nich pokazuje ona, do czego może doprowadzić i często prowadzi zakaz terminowania ciąży (Waniek b.d.). Jeszcze bardziej wprost problem przerywania ciąży został wyrażony w utworze No name. Tu co prawda tekst jest współczesny, jedynie stylizowany na wiejską balladę, jednak zestawiony ze wschodnio brzmiącym dźwiękiem tureckiego rebabu a później $\mathrm{z}$ rockowym uderzeniem, staje się niezwykle mocnym przekazem:

Dłonie metalowe pogłaszczą twą głowę, chwilkę poszczypie, chwilkę poszczypie. W ciepłej krwi w koszyku, już po bólu, po krzyku, na brzeg zaniosę cię, na brzeg zaniosę cię, pod ramiona tęczy... Odpłyń moje małe, ukochane dziecię, za życia rzekę, za życia rzekę.

Niech ciebie nie bolą złe sprawy człowiecze. (Same Suki 2018)

Warto dodać, że pod względem muzycznym twórczość Samych Suk właściwie można byłoby określić jako World Music. One same nazywają swoją muzykę eklektyczną. A zatem odnajdziemy tu i nawiązania do polskiej tradycji wiejskiej, ale też brzmienia bliskowschodnie, rytmy i pulsowanie nawiązujące do tradycji środkowoafrykańskich, a także odwołania do zachodnich gatunków muzycznych, takich jak rock czy

$5 \quad$ Na przykład folk-metalowy zespół Żmij. 
punk. Sądzę, że to łączenie różnych stylistyk można odczytywać jako komunikat o uniwersalności kobiecego doświadczenia.

W 2016 r. powstała jeszcze jedna interesująca muzyczna formacja feministyczna - Chór Czarownic. Teksty śpiewane, a może raczej krzyczane i szeptane przez kobiety w różnym wieku, są pisane współcześnie, jednak „chórzystki” odwołują się do tradycji śpiewu białego, a także do historii oskarżeń o czary. Jak pisała Agata Stanisz (2018: 91),

[w] protest songach chóru manifestowana jest niezgoda na dyskryminację i wykorzystywanie ze względu na płeć. Utwory te dotykają ważnych, poruszanych przez współczesne feministki kwestii [...], takich jak genderyzacja sfery publicznej i prywatnej, kulturowe oczekiwania wobec kobiet, ich cielesność i uprzedmiotowienie, historia prześladowania, problem przemocy oraz gwałtu.

Z punktu widzenia polityczności omówionych powyżej folkowych projektów najbardziej interesujący wydaje mi się fakt, że w momentach społecznego wrzenia stają się one nie tylko artystyczną formą wyrazu określonych poglądów, ale zaczynają funkcjonować jako ścieżka dźwiękowa działań o jawnie politycznym charakterze - przede wszystkim protestów i demonstracji. Szczególne znaczenie, ale i popularność zyskują one w sytuacjach silnych napięć i kryzysów społeczno-politycznych, których przykładem mogą być działania kobiet walczących o swoje podstawowe prawa po wyroku Trybunału Konstytucyjnego z 22 października 2020 r. ${ }^{6}$ Radykalne zaostrzenie ustawy aborcyjnej wywołało masowe protesty, które ogarnęły nie tylko wielkie miasta, ale cały kraj, zaś ważnym elementem tych demonstracji stała się właśnie muzyka. Niektórzy pisali wręcz o najbardziej roztańczonej rewolucji, o „wkurwionym” karnawale, a także o tym, że „[ż]aden z wcześniejszych protestów w bogatej w protesty historii III Rzeczpospolitej nie miał tak różnorodnej i wyrazistej ścieżki dźwiękowej” (Szwed 2020). Ten soundtrack protestów z 2020 i 2021 r. był wyjątkowy także dlatego, że w mniejszym stopniu czerpał ze starych, sprawdzonych protest songów spod znaków Murów Jacka Kaczmarskiego, a w większym wykorzystywał nowe utwory - albo skomponowane właśnie jako reakcja na działania władzy, albo powstałe wcześniej, ale niosące treści feministyczne. Wśród nich pojawiły się także piosenki omawianych przeze mnie wcześniej zespołów, m.in. Twoja władza Chóru Czarownic (2017), która już w 2016 r. stała się dźwiękowym symbolem tzw. czarnych protestów. W roku 2020 skandowana była przez tłum z jeszcze większą mocą. Z kolei zespół R.U.T.A. na znak wsparcia kobiet przypomniał na swoim profilu facebookowym utwór Precz!, tym razem adresując go nie do panów pańszczyźnianych, ale do rządu. Z samochodów prowadzących marsze rozbrzmiewały także Same Suki. Muzyka w tych sytuacjach stawała się, jak chciał John Street (2012), czystą polityczną ekspresją. Nie była jedynie wyrażaniem

6 Wedle orzeczenia Trybunału Konstytucyjnego niezgodne z konstytuują i traktowane jak przestępstwo jest przerywanie ciąży ze względu na ciężkie warunki życiowe lub trudną sytuację osobistą kobiety ciężarnej, a także (co budzi największe oburzenie) „gdy badania prenatalne lub inne przesłanki medyczne wskazują na duże prawdopodobieństwo ciężkiego i nieodwracalnego upośledzenia płodu albo nieuleczalnej choroby zagrażającej jego życiu“ (Sygn. akt K 1/20). 
światopoglądu, lecz raczej rewolucją. Z pewnością przyczyniała się do konstruowania zbiorowych tożsamości i usiłowała zmieniać porządek społeczny (deNora 200o), a zaangażowani w nią ludzie naprawdę wierzyli w moc zmiany relacji władzy (Mahon 2014).

Niezwykle ważne wydają mi się także te momenty strajkowej aktywności kobiet, kiedy nie tylko odtwarzają one muzykę, ale same angażują się w nią głosem i ciałem, kiedy biorą czynny udział w muzycznym rytuale, który Christopher Small (1999) nazwał to music. Tak stało się na przykład 1 listopada 2020 r. na wrocławskim rynku, gdzie z inicjatywy Gabinetu Głosu odbył się performance pod hasłem „Synchronizacja cykli”. Zebrane na placu kobiety połączyły swoje głosy w jeden, śpiewając Rutę - tradycyjną pieśń weselną z Dolnego Śląska (Gabinet Głosu 2020). Całkiem spontanicznie folkowym hymnem protestujących uczyniono natomiast pieśń włoskich partyzantów antyfaszystowskich z 1942 r. Bella ciao. Po raz pierwszy, ze zmienionym tekstem, na tle syren policyjnych zaśpiewała ją Łaja Szkło, pieśniarka, którą również można umieścić w nurcie stylistyki folkowej. $\mathrm{Z}$ akordeonem w rękach, stojąc na ulicy, śpiewała:

Więc jeśli nie chcesz swojemu ciału powiedzieć ciao, ciało, ciao, ciao, ciało ciao, ciao!

To bierz transparent jak inne siostry i bunt swój po ulicy nieś.

Niech płonie nasz gniew w tysiącach gardeł, co krzyczą: dość ofiarom, dość ofiarom, wara od nas wiaro!

Jesteśmy równe, jesteśmy wolne i świat usłyszy naszą pieśń!

(Masny Jimmy 2020)

Ta pieśń szybko stała się jednym z elementów współczesnego folkloru demonstracji. Większość protestujących nie wiedziała pewnie nawet, skąd ona pochodzi i jakie ma autorstwo. Zanonimizowana stała się wyrazicielką gniewu wielu protestujących i śpiewana była niemal na każdej demonstracji. Spełniła swoje rytualne i polityczne jednocześnie zadanie. Jednoczyła ludzi w celebracji wspólnej wizji świata i podzielanych wartości (Small 1999), a jednocześnie wzywała do działania. Sądzę, że tak jak wiele innych przywołanych przeze mnie utworów folkowych, pieśn ta jest dziś polityką sensu stricto (Street 2012).

Przyglądając się współczesnemu światu, niepokojom społecznym wybuchającym w wielu jego miejscach i działaniom zwykłych ludzi dążących do wyrażenia swojego zdania i przede wszystkim gotowych do pokojowej walki o własne prawa, nie mam wątpliwości, że ważnym narzędziem oporu jest muzyka (por. Stanisz 2018; Orejuela, Shonekan 2018). Sądzę też, że taka właśnie polityczna funkcja muzyki nie jest wymysłem naszych czasów. Śpiewanie o swoim złym losie, zagrzewanie dźwiękami do walki z opresorem, próby dźwiękowego rekompensowania niesprawiedliwości lub godzenia się ze złą rzeczywistością - to w moim pojęciu zjawiska 
ponadczasowe i uniwersalne.

Zestawienie pieśni śpiewanych przez wiejskie kobiety w XIX w. ze współczesnymi utworami folkowymi o tematyce feministycznej zdaje się doskonałym argumentem na rzecz tak sformułowanej tezy. I choć nasze przodkinie bez wątpienia miały los znacznie gorszy niż my - współczesne Polki, zaskakująco wiele tematów, które pojawiają się w tekstach pieśni zapisanych przez Oskara Kolberga, wciąż pozostaje aktualnych: przemoc domowa, nadużycia seksualne, podporządkowana rola kobiet w życiu społecznym i politycznym, próby ograniczania kobietom możliwości decydowania o sobie. Między innymi śpiewając, kobiety niosły i nadal niosą swój bunt - po wiejskich drogach i miejskich ulicach.

\section{BIBLIOGRAFIA}

Burszta, J. (1950). Wieś i karczma. Rola karczmy w życiu wsi pańszczyźnianej. Warszawa: Ludowa Spółdzielnia wydawnicza.

Chór Czarownic (2017, 2 października). Chór Czarownic The Witches’ Choir - Twoja władza [plik wideo]. Pobrano z: https://www.youtube.com/watch?v=UCYH3O_egDI

Dahlig, P. (1987). Muzyka ludowa we wspótczesnym społeczeństwie. Warszawa: Wydawnictwa Szkolne i Pedagogiczne.

DeNora, T. (200o). Music in Everyday Life. Cambridge: Cambrigde University Press.

Dobrowolski, M., Szajkowski, M. (2011). Historie krwią pisane. Z Maciejem Szajkowskim rozmawia Mateusz Dobrowolski. Gadki z Chatki, 92/93. Pobrano z: http://gadki.lublin.pl/gadki/artykul.php?nr_ $\operatorname{art}=1883$

Gabinet Głosu (2020, 1 listopada). Pieśni Synchronizujące Cykle - Ruta (Wrocław, Rynek) [plik wideo]. Pobrano z: https://www.youtube.com/watch?v=T5aW-1RgEOs

Grozdew-Kołacińska, W. (2014). Myśli i dzieło Oskara Kolberga jako inspiracja dla współczesnego etnomuzykologa. Lud, 98, 63-80.

Gwizdalanka, D. (1999). Muzyka i polityka. Kraków: PWM.

Kizińska, K. (2012) Gender a kultury muzyczne - kulturoznawcze spojrzenie na badania etnomuzykologiczne i historyczne. Przeglad Kulturoznawczy, 15(4), 382-390. doi 10.4467/2084386oPK.12.032.0995

Kolberg, O. (1962). Dzieła wszystkie: T. 2. Sandomierskie. Wrocław-Poznań: Polskie Towarzystwo Ludoznawcze, Polskie Wydawnictwo Muzyczne, Ludowa Spółdzielnia Wydawnicza.

Kolberg, O. (1963a). Dzieła wszystkie: T. 9. Wielkie Księstwo Poznańskie: Cz. 1. Wrocław-Poznań: Polskie Towarzystwo Ludoznawcze, Polskie Wydawnictwo Muzyczne, Ludowa Spółdzielnia Wydawnicza.

Kolberg, O. (1963b). Dzieła wszystkie: T. 25. Mazowsze: Cz. 2. Wrocław-Poznań: Polskie Towarzystwo Ludoznawcze, Polskie Wydawnictwo Muzyczne, Ludowa Spółdzielnia Wydawnicza.

Kolberg, O. (1963c). Dzieła wszystkie: T. 12. Wielkie Księstwo Poznańskie: Cz. 4. Wrocław-Poznań: Polskie Towarzystwo Ludoznawcze, Polskie Wydawnictwo Muzyczne, Ludowa Spółdzielnia Wydawnicza.

Kolberg, O. (1963d). Dzieła wszystkie: T.6. Krakowskie: Cz. 2. Wrocław-Poznań: Polskie Towarzystwo Ludoznawcze, Polskie Wydawnictwo Muzyczne, Ludowa Spółdzielnia Wydawnicza.

Kolberg, O. (1964). Dzieła wszystkie: T. 27. Mazowsze: Cz. 4. Wrocław-Poznań: Polskie Towarzystwo Ludoznawcze, Polskie Wydawnictwo Muzyczne, Ludowa Spółdzielnia Wydawnicza.

Kolberg, O. (1964a). Dzieła wszystkie: T. 28. Mazowsze: cz. 5. Wrocław-Poznań: Polskie Towarzystwo Ludoznawcze, Polskie Wydawnictwo Muzyczne, Ludowa Spółdzielnia Wydawnicza.

Kolberg, O. (1968). Dzieła wszystkie: T. 44. Góry i Podgórze: Cz. 1. Wrocław-Poznań: Polskie Towarzystwo Ludoznawcze, Polskie Wydawnictwo Muzyczne, Ludowa Spółdzielnia Wydawnicza. 
Koskoff, E. (2014). A Feminist Ethnomusicology: Writings on Music and Gender. Chicago: University of Illinois Press.

Kowalski, P. (2004). O kulturze ludowej i tym, co z nią się robi. W: P. Kowalski, Popkultura i humaniści. Daleki od kompletności remanent spraw, poglądów i mistyfikacji (ss. 145-168). Kraków: Wydawnictwo Uniwersytetu Jagiellońskiego.

Kowalski, R. (2011, 18 sierpnia). PiS kontra R.U.T.A. [artykuł na portalu wyborcza.pl]. Pobrano z: https://wyborcza.pl/1,75398,10130910,PiS_kontra_R_U_T_A.html

Leszczyński, A. (2020). Ludowa historia Polski. Warszawa: WAB

Mahon, M. (2014). Music, Power, and Practice. Ethnomusicology, 58(2), 327-333. doi.org/10.5406/ethnomusicology.58.2.0327

Małanicz-Przybylska, M. (2014). Góralskie muzyczki i muzykantki - kobiety w kulturze muzycznej współczesnego Skalnego Podhala. Lud, 98, 277-298.

Masny Jimmy (2020, 28 października). Fenomenalna interpretacja Bella Ciao na \#StrajkKobiet [plik wideo]. Pobrano z: https://www.youtube.com/watch?v=nRhr54r9GN4

Mędrzecki, W. (1995). Kobieta wiejska w Królestwie Polskim. Przełom XIX i XX wieku. W: A. Żarnowska, A. Szwarc (red.), Kobieta i społeczeństwo na ziemiach polskich w XIX wieku. Warszawa: Wydawnictwo DiG.

Myśliwski, W. (2003). Kres kultury chłopskiej. Warszawa-Bochnia: Prowincjonalna Oficyna Wydawnicza.

Nowak, T. (2016). Muzykantki w kulturze muzycznej wsi polskiej. Zarys problematyki. Etnomuzykologia Polska, 1, 44-48.

Orejuela, F., Shonekan, S. (2018). Black Lives Matter and Music: Protest, Intervention, Reflection. Bloomington: Indiana University Press.

O Samych Sukach (b.d.). Same Suki [strona internetowa]. Pobrano z: https://samesuki.pl/pl/o-samychsukach/

Pobłocki, K. (2021). Chamstwo. Wołowiec: Czarne.

Pochwalone (b.d.). Antena krzyku [strona internetowa]. Pobrano z: http://www.antenakrzyku.pl/pl/ sklep/pochwalone-czarny-war-cd/

Rauszer, M. (2020). Bękarty pańszczyzny. Warszawa: Wydawnictwo RM.

Small, Ch. (1999). Musicking - the meanings of performing and listening. A lecture. Music Education Research 1(1), 9-22. doi: 10.1080/1461380990010102

Stanisz, A. (2018). Antropologia dźwięku wobec protestów społecznych i politycznych. Zeszyty Naukowe Uniwersytetu Jagiellońskiego. Prace Etnograficzne, 46(1), 89-115. doi:10.4467/22999558.PE.17.005.8686

Stomma, L. (1986). Antropologia kultury wsi polskiej XIX w. Warszawa: Państwowy Instytut Wydawniczy.

Street, J. (2012). Music and Politics. Cambridge-Malden: Polity.

Szwed, P. (2020). Wk*****ny karnawał. Dwutygodnik.com. Strona kultury, 293(10). Pobrano z: https://www.dwutygodnik.com/artykul/9199-wkny-karnawal.html

Waniek, K. (b.d.), Siedem [wpis na blogu]. Pobrano z: http://aborcja.org/siedem/

Waszczyńska, K. (2014). Metody pracy, zasady i praktyka podziału regionalnego w monografiach Oskara Kolberga. Lud, 98, 17-40.

Wiechnik, O. (2014, 29 lipca). Same Suki - wiejska bojówka [artykuł w serwisie wysokieobcasy.pl]. Pobrano z: https://www.wysokieobcasy.pl/wysokie-obcasy/1,96856,16372048,Same_Suki___wiejska_bojowka.html

Wiślicz, T. (2012). Wiejskie zaloty w Polsce XVII-XVIII wieku. Sposoby doboru partnera seksualnego i kryteria atrakcyjności w środowisku chłopskim Rzeczypospolitej w okresie „przedetnograficznym”. Studia Historica Gedanensia, 3, 37-57.

Wiślicz, T. (2014). Dzieciobójstwo jako narzędzie polityki reprodukcyjnej w Rzeczypospolitej XVIIXVIII wieku. W: B. Popiołek, A. Chłosta-Sikorska, M. Gadocha (red.), W kręgu rodziny epok dawnych. Dzieciństwo (s. 141-151). Warszawa: DiG.

Wiślicz, T. (2017). Fabrykacja nierządnicy, czyli o ofiarach względnej swobody seksualnej na polskiej wsi przedrozbiorowej. Lud, 101, 129-148. doi.org/10.12775/lud101.2017.03 


\section{DYSKOGRAFIA:}

Kapela ze Wsi Warszawa (2001). Wiosna ludu [CD]. Orange World.

Kapela ze Wsi Warszawa (2004). Wykorzenienie [CD]. Jaro Medien.

Pochwalone (2013). Czarny war [CD]. Antena krzyku.

R.U.T.A. (2011). Gore - Pieśni buntu i niedoli XVI-XX wieku [CD]. Karrot Kommando.

R.U.T.A. (2012). Na uschod. Wolność albo śmierć [CD]. Karrot Kommando.

Same Suki (2013). Niewierne [CD]. Sonic Records.

Same Suki (2018). Ach mój Borze [CD]. Sonic Records. 